\title{
THE SALVAGING OF CIVILISATION
}

CIVILISATION is in peril. Press and pulpit proclaim the fact. Politicians make its salvation their appeal to popular suffrage, and communists hail its fall as an unqualified blessing.

Of what nature is the menace to civilisation? Politicians call it Bolshevism, and communists call it the Class War. The politician and his party papers see the finger of Bolshevism in Ireland, in the German Reparations difficulty and in every industrial dispute at home and abroad. All labour members of Parliament, all trade unionists, all co-operators, all socialists are Bolshevists and, ipso facto, enemies of the existing order of society. With equal intolerance, communists regard all who compromise with society and its institutions as lacking in class-consciousness and enemies of the proletariat.

The communist is a socialist in a hurry, and that is why he has lost all sense of proportion. It is futile, he argues, to suppose that a majority of the people, who could express their will in a constitutional manner, can ever be converted to the principles of communism. A leaven of communists, a coup d'êtat, and civilisation will be overthrown. The real work of conversion can then begin. There must be rigorous suppression of all that is antagonistic to the new order of society. Force alone will prevail with the grown-ups, for their mentality has already been warped. They are capitalistically minded, and only the practical demonstration of the superiority of communism will reconcile them to the new order. The children will present no such difficulty. They will grow up in the 


\section{Blackfriars}

new order as their fathers grew up in the old. Two generations should see the end of proletarian dictatorship.

The communist is not without an ethical basis for his creed. He is out to save the masses from economic perdition, and he will save them whether they like it or not. He feels he is right; he knows he is right. $\mathrm{He}$ is not with the majority, but is not the majority always wrong?

Communism has made great strides throughout Europe and in America since the signing of the Armistice in 1918. In Russia it holds sway, and spasmodic outbreaks have been witnessed in Germany, in the Spartacist revolts; in Hungary, under Bela Kun; in Italy, where factories were seized and worked by the operatives; in France and, to some small extent, in England. In its success it has been ruthless, and in its failure as ruthlessly suppressed.

All existing civilised governments fear communism. In it, and in it alone, they see the menace to civilisation. Communism in the abstract they do not fear. As an economic order of society they would probably hail it as a great and noble ideal. What they fear is that that great and noble ideal would never be realised, that rather existing civilisation would be swamped by a wave of barbarism. Politicians are realists; they have no faith in human nature. Love of gain and fear of poverty are the only spurs to effort, they say. Agreed, says the communist, but men must be made to see that the only sound economic principle is 'from each according to his ability, to each according to his need.'

During the coal dispute of 1920, the Government, fearing that the transport workers and railwaymen would be involved, raised a Defence Force and threw a number of communists into prison. Colour was thus lent to the claim of the communists that the class war 


\section{The Salvaging of Civilisation}

was a reality. This persecution of communists went on long after the disbandment of the Defence Force, but it now appears to have wholly died down. These measures are, nevertheless, symptomatic. They imply a fear of impending social upheaval in the minds of the governing body.

But this fear of social upheaval prevails not only in the minds of the wealthy classes, but also in the minds of the middle and lower orders. The middle classes, it is important to note, are now hailed by Labour as workers, but this is not strictly true. 'Workers by hand or brain' sounds very well, but the brain-worker is usually a salaried person with a fairly secure tenure, whereas the manual worker lives from hand to mouth and has no security. This it is which draws a dividing line between the professional and working classes. The professional classes feel that communism will restrict their liberties and lessen their pleasures. The working classes live in perpetual hope of climbing up on to a higher social plane, and suspect communism of wishing to keep them all on one dead level.

But the masses are no more interested in political or economic philosophy than they are in ethics or religion. Their apathy is indestructible, save by famine or pestilence-two remote contingencies in the present highly organised form of society. A materialism, as unreasoned as that of their rulers is reasoned, is theirs. 'Eat, drink and be merry, for to-morrow we die.'

It is reasoned materialism that gives rise to the advocacy of increased divorce facilities and birth control. It is unreasoned materialism which demands or accepts these things on the part of the masses. Why deny to the poor what the rich can purchase with money? The Harley Street physician will, for a heavy fee, tell the lady of wealth and position how she may limit her family. Why should not this knowledge be 


\section{Blackfriars}

democratised? True democracy demands that all should eat of the tree of knowledge of good and evil.

The tendency of democratic government is towards a more equitable distribution of wealth, a levelling process which implies more of the good things of life for some and less for others. 'The more the merrier,' the 'have-nots' may cry, but 'the fewer the better fare' is the reply of the 'haves.' In effect, the working classes are being told that there are too many of them, that their wealth, their liberties, their pleasures are restricted by the size of their families.

All this is true if life is an end in itself. 'I cannot repress my natural instincts,' is the unspoken comment of the working man, 'social conditions are against me. The housing question alone makes it im possible.' 'True,' answers the birth controller, 'but we do not ask you to exercise moral restraint. We recognise that as an impossible demand. Only give ear to our scientific teaching and you may give full play to your animal instincts with no fear of natural consequences.'

A new Malthusianism, for Malthus himself counselled moral restraint! If democracy be an apt learner, it will push these counsels to their logical conclusion and deny the necessity of marriage. Against this racial suicide stands one force alone-the Catholic Church.

This general philosophy of life, recognised by leading statesmen as materialistic and as a menace to existing civilisation, will act and re-act in the legislation of the future. Not the merits of party, but the attitude of parliamentary candidates towards these basic questions of morality, must determine the vote of the Catholic elector. Only thus can civilisation be salvaged from the waves of materialism.

C. P. Le Huray. 